\title{
Optimization of National Rice Production with Fuzzy Logic using Mamdani Method
}

\author{
Wawan Wawan*, Mai Zuniati, and Agus Setiawan
}

\begin{abstract}
\begin{tabular}{l|l|l|l}
\hline Received : August 22, 2020 & Revised : October 2, 2020 & Accepted : November 27, 2020 & Online : November 29, 2020 \\
\hline
\end{tabular}
\section{Abstract}

The purpose of this article is to optimization of national rice production with fuzzy logic using Mamdani method. Based on the results of the study, it is known that four parameters need to be considered to maintain the price stability of necessities, namely production; availability; demand and distribution. Optimization of production by producers and optimization of the ordering of goods by distributors are important steps to maintain price stability for necessities. Optimization of production and ordering of staple goods will have a significant impact on the financial sector because it is closely related to the prediction of the number of raw materials used, production costs, storage costs, and also distribution costs of goods. One of the fuzzy inference methods that can be used for this optimization is the Mamdani method. To get the output on the application of the fuzzy logic of the Mamdani method, four stages are needed, formation of fuzzy sets; application of implication functions; composition of rules and defuzzification. Fuzzy logic Mamdani method can be used to predict the amount of national rice that must be produced. If it is known that the need is $21,908,784$ tons of rice and the supply is $65,457,456$ tons, the amount of national rice that must be produced is $14,624,592$ tons.
\end{abstract}

Keywords: fuzzy inference, mamdani method, rice production

\section{INTRODUCTION}

Seen on a global scale, food security remains a serious problem, especially in developing countries where challenges of sustainable food supply are exacerbated by rapid population increases, limited access to food intake, vulnerability, price volatility, protective measures imposed by governments, and so on [1]. Several studies have shown that food insecurity is influenced by various factors, including population growth, availability of fertile land and water resources, and climate change [2]. Indonesia is one of the developing countries that have fairly good food security. As an indicator, The people in Indonesia are guaranteed a sustainable supply of food and other necessities. Even so, there is often instability in the prices of necessities, especially before the religious holidays. As a consequence, people's purchasing power decreases and the fulfillment of primary needs is limited, even though their availability is abundant This is certainly material for self-evaluation for policymakers in finding solutions so that prices of staple goods are always stable

\section{Copyright Holder:}

(C) Wawan, W., Zuniati, M., and Setiawan, A. (2021)

\section{First Publication Right:}

Journal of Multidisciplinary Applied Natural Science

This Article is Licensed Under: so that it has an impact on the welfare of the community [3].

It must be admitted that rice and other staple goods, such as meat, cooking oil, salt, and sugar, are the most important commodities in Indonesia because of their role as a staple food, which the majority of every Indonesian population consumes every day as nutritional intake. Not only that, various staple goods are also a dominant strategic commodity in the Indonesian economy because they are closely related to monetary policy and involve socio -political issues. To meet these needs, many things affect the stability of availability and price, starting from climatic conditions, logistics systems, and domestic market conditions as well as global market conditions.

When examined further, price movements of staple goods, especially rice, are strongly influenced by three factors [4]. The first factor is the factor of the availability of the goods themselves, which comes from the crops of the farmers for rice and corn; the production of meat, eggs, and milk from the farmers and the production from the company for other necessities such as sugar and cooking oil. The second factor is the demand factor from consumers. Consumer demand is often influenced by several factors, for example an increase in demand ahead of National Religious Holidays; panic or consumer concerns about the scarcity of various commodities in the market and changes in consumption 
patterns, preferences, and diversification of staple foods consumer. The third factor is the distribution factor that can trigger an increase and decrease in the price of necessities. The distribution process incurs several costs, such as the number of distribution costs, the distance from the production center to the consumption center, and the disruption in the distribution process.

Indonesia has no longer been able to be rice self -sufficient since 1984. The deficit forced the government to import rice from the Philippines and Thailand as a result of great demand. It is difficult to know so many variables that cause rice selfsufficiency. It could be induced, for example, by weak agricultural infrastructure in Indonesia, government policies, a lack of land to open up new fields, as well as a lack of labor. Given that Indonesia is a vast tropical area and also has ample human capital, this is rather ironic. The government is still trying to find a solution so that it is possible to solve the rice self-sufficiency problem and increase the welfare of the citizens of Indonesia. Therefore any policy determined whether it will work in the rice self-sufficiency program must be re-evaluated by the government. The performance of government policy would have an effect on the increase in the amount of rice production. One way to quantify uncertainty in forecasting using the Fuzzy Logic of the Mamdani method is to calculate the amount of rice production that is uncertain [4].

Taking into account these few things, there are at least four things that need to be considered in maintaining the price stability of staple goods, namely: production; availability; demand and distribution. Furthermore, in this article, we will see how fuzzy logic contributes to controlling the price of staple goods. In this article, we will also provide an example of how to optimize production using the Mamdani method of fuzzy logic application. This procedure is an important part of providing a reference for producers and distributors of necessities in managing the supply chain to minimize the costs of production and distribution of goods. As a final implication, the stability of prices for necessities on the market is maintained. Based on this explanation, the purpose of writing articles are as follows providing knowledge related to the use of the Fuzzy Mamdani method in the optimization of production and ordering of national rice.

\section{METHODOLOGY}

\subsection{Fuzzy Logic}

Fuzzy can be interpreted as fuzzy or vague. Fuzzy logic is a set of mathematical principles for the representation of knowledge based on the degree of membership [5]. Fuzzy logic is a form of many logical values; relates to the use of reasoning for approximations. Compared to traditional or classical binary sets (where variables can take true or false values), fuzzy logic variables have truth values that range in levels between 0 and 1. Fuzzy logic itself has been extended to deal with the concept of partial truth, where the truth of value can range between completely true and completely false [6].

\subsection{Linguistic Variables}

If a variable uses words in the colloquial language as its value, then the variable is called a linguistic variable, where words are characterized by a vague set defined in a defined universe of variables [7]. Linguistic variables are defined as variables whose value is predictive statements, economic planning, and management, in natural or artificial language [8]. With the concept of linguistic variables, words can be used as the value of a variable. In essence, a fuzzy variable is a symbol or word that points to something that is not certain in the fuzzy system. Example: demand, supply, production, and so on. In general, the value of a linguistic variable is the combined term $x=x_{1}, \quad x_{2} \ldots x_{n}$ which is a series of structured terms Structured terms $x_{1}, x_{2}, \ldots x_{n}$ can be classified into three groups, namely as follows.

1. The primary term, which is the name of the cryptic set, for example: low, medium, and high.

2. The complement of "not" and the "and" and "or" connector.

3. Limits, such as: very, more than or less than and so on [7].

\subsection{Fuzzy set}

Fuzzy set theory was first introduced by Zadeh in 1965 . He was compelled to observe that human reasoning can take advantage of concepts and knowledge that do not have welldefined boundaries [9]. Fuzzy set theory is a generalization of ordinary or classical set theo- 
ry. Fuzzy is useful for checking many real problems related to fuzzy logic. In a fuzzy set, the membership of an element in a set is expressed by its degree of membership. The fuzzy set $\mathrm{A}$ in the universal set $\mathrm{U}$ can be represented by the membership function $\mu$ A which takes the values in the interval [0,1] [7]. In the fuzzy set, the membership values are in the range 0 to 1 . If $x$ has a fuzzy membership value

$\square \mu{ }_{-} \mathrm{A}(\mathrm{x})=0$ means $\mathrm{x}$ is not a member of set $A$, likewise if $x$ has a fuzzy membership value $\mu \_A(x)=1$ means $x$ becomes a full member of set A. In fuzzy membership, this value provides a measure of opinion or decision. Fuzzy sets have 2 attributes, namely: (a) Linguistics, which is the naming of a group that has a certain condition or condition using language, such as: young, middle, old, and (b) numerical, which is a value (number) indicating the size of a variable such as 10, 15, 20 and so on [10].

\subsection{Membership Functions}

The membership function is a curve that shows the mapping of data input points into membership values that have an interval between 0 and 1 . One way that can be used to get membership value is through a functional approach. Some of the functions that can be used include: (a) linear representation, (b) triangle curve representation, (c) trapezium curve representation, and (d) shoulder shape curve representation [10].

\subsection{Implication function}

The cryptic IF-THEN rule is a condition statement with the expression: IF <cryptic proposition>, THEN <cryptic proposition>. The truth or error of a cryptic proposition is a matter of degree (degree). There are two types of cryptic measures, namely atomic fuzzy propositions and compound fuzzy propositions [7]. Combined cryptic propositions can be understood as cryptic relations [7]. Here's how to determine the membership function of cryptic relations.

- To connect "and" use a faint wedge. Let $\mathrm{x}$ and $y$ be linguistic variables in the physical domains $\mathrm{U}$ and $\mathrm{V}$, and $\mathrm{A}$ and $\mathrm{B}$ represent equivocal sets in $\mathrm{U}$ and $\mathrm{V}$, then the compound cryptic proposition: $x$ is $A$ and $y$ is $B$

interpreted as the cryptic relation $\mathrm{A} \cap \mathrm{B}$ in $\mathrm{U}$ $\times \mathrm{V}$ with a membership function

$$
\mu_{A \cap B}(x, y)=t\left[\mu_{A}(x), \mu_{B}(y)\right]
$$

where t: $[0,1] \times[0,1] \rightarrow[0,1]$ for any $t-$ norm

- For "or" conjunctions, use cryptic joins. Combined cryptic proposition:

$$
x \text { is } A \text { or } y \text { is } B
$$

interpreted as the cryptic relation $A \cup B$ in $\mathrm{U} \times \mathrm{V}$ with the membership function:

$$
\mu_{A \cup B}(x, y)=s\left[\mu_{A}(x), \mu_{B}(x)\right]
$$

where $s:[0,1] \times[0,1] \rightarrow[0,1]$ for any t-norm

- To connect "not" using the cryptic compliment. The cryptic set of notes A (not A) is replaced with

\subsection{Mamdani Implica- tion}

The Mamdani meth- ${ }^{\bar{A}}$ od of fuzzy inference system is also known as the Max-Min method [10]. The Mamdani method works based on linguistic rules. This method was introduced by Ebrahim H. Mamdani in 1975. The Mamdani implication is supported by the argument that the cryptic IF-THEN rule is local. The cryptic IF-THEN rule is interpreted as the cryptic relation $Q_{M M}$ or $Q_{M P}$ in $\mathrm{U} \times \mathrm{V}$ with the following membership function [7].

$$
\begin{aligned}
& \mu_{Q M M}(x, y)=\min \left[\mu_{F P_{1}}(x), \mu_{F P_{2}}(y)\right] \\
& \mu_{Q_{M P}}(x, y)=\mu_{F P_{1}}(x) \mu_{F P_{2}}(y)
\end{aligned}
$$

\section{RESULTS AND DISCUSSION}

It has been mentioned earlier that controlling the prices of basic needs involves four things, namely: (1) the production process, (2) the availability of goods, (3) the amount of market demand or com- 
munity needs, and (4) the cost of distributing goods. Producers and distributors contribute significantly to the price of necessities in the market. For several important commodities such as rice, the amount of agricultural production, availability in Bulog, and community needs greatly affect the price of rice. For producers providing other staple goods such as cooking oil, sugar, milk, and other staples, the optimization of production will have major implications for the selling price in the market. Optimization of the production of staple goods will affect the financial sector because it is closely related to estimates of raw materials, production costs, storage costs, and also distribution costs of goods. As part of controlling the prices of necessities, the production optimization process is important. On the other hand, distributors also play a crucial role in maintaining the price stability of necessities. Distributors must be careful in ordering products from producers. Of course, ordering products must also be adjusted to the availability of goods and market demand. If the distributor is not careful in this matter, it can have implications for the distributor's loss.

In this regard, fuzzy logic can be used in optimizing various sectors to control prices for necessities in the market. For producers, fuzzy logic can contribute to the optimization of production, while distributors can be used in optimizing orders from producers. The fuzzy approach can be effectively utilized to deal with imprecision and uncertainty [11]. This approach can be used for performance evaluation that allows organizations, producers, or distributors to carry out professional assessments in evaluating the supply chain of staple goods. In real problems in the field, performance evaluation techniques with Fuzzy logic can be used to handle cases such as subjectivity, obscurity, and imprecise information. The application of fuzzy set theory in evaluation systems can improve evaluation results [12].

When viewed historically, the initial idea of applying fuzzy sets to control problems is presented more explicitly by Chang and Zadeh [13]. In subsequent developments, research has been carried out on real problems initiated by Mamdani and Assilian [14] and Mamdani [15]. Until now, there have been many studies using Fuzzy logic in the case of controlling the prices of necessities, for example, research [16] has provided an application for the problem of cryptic production inventory planning using the optimality equation. Many studies have included distortion factors in preparing the optimization of production quantities. For example [17] developed and investigated the Economic Order Quantity (EOQ) model in the fuzzy sense by considering stochastic demand, partial backlogging, and the degree of fuzzy damage. The proposed model is also extended to the case where the partial backlogging factor is assumed to be a fuzzy number. The total minimum cost and optimal order quantity are obtained by defuzzifying the total cost through the signed distance method. Nagoor Gani and Maheswari [18] discussed the retailer's ordering policy of two levels of late payment taking into account the selling price per item being higher than the purchase cost per item. The demand and selling price per item is taken as triangular fuzzy numbers. The function principle is used to calculate the optimal cycle times and the economical order quantity. The method of representation of the tiered average integration is used for defuzzification in this case.

Another study, Lee and Yaou [19] developed the Economic Production Quantity (EPQ) model in which demand and production quantity are assumed to be vague. Then Lo et al. [20] presented the EPQ model which includes uncertain factors such as unreliable machines, defective products, or imperfect goods. They have used the EPQ model to explore the most economical choice of production cost factors based on the uncertainties that may exist. Furthermore, Chen and Chang [21] developed an EPQ model with irreparably defective production yields. Chang [22] discusses how to get the economic order quantity, when the quantity demanded is uncertain. While Lee and Yao [19] and Lin and Yao [23] have also written several articles on cryptic production models, they have not yet developed an inventory model with imperfect products. An inventory model with imperfect products was carried out by Chen, et al. [24] who proposed a Fuzzy Economic Production Quantity (FEPQ) model with imperfect products that can be sold at a discount. In this model, costs and quantities are expressed as trapezoidal fuzzy numbers.

These various studies have provided important references regarding the contribution of fuzzy logic in controlling the prices of necessities. Optimization of production and ordering of goods by considering various things such as machine reliability, imper- 
fections in production, availability of imperfect or defective products, and uncertain market demand is urgent considerations in planning the supply of staple goods. Fuzzy logic has made a valuable contribution in controlling the prices of necessities.

An important part of fuzzy logic is represented by Fuzzy Logic Control (FLC), derived from control theory based on the mathematical model of an open-loop process to control. FLC has been successfully applied to a variety of practical problems such as control of warm water, robots, heat exchange, traffic at intersections, car speed, automotive engineering, washing machines, and so on [25]. In connection with the optimization of production and ordering of staple goods, several methods can be used in the application of fuzzy logic in this field, for example, the Mamdani method, the Tsukamoto method, and the Sugeno method.

As presented Iancu [25], the most commonly used fuzzy inference technique is the Mamdani method proposed by Mamdani and Assilian [14], as a first attempt to control a steam engine and boiler combination by synthesizing a set of linguistic rule controls obtained from experienced human operators. The work was inspired by the equally influential publication of [8]. Interest in fuzzy control has continued since then, and the literature on the subject has grown rapidly to date.

In the Mamdani method, the fuzzy implications are modeled by the Mamdani minimum operator, the conjunction operator is min, the t-norm of the min composition rule, and for rule aggregation, the max operator is used. According to Iancu [25] there are four steps in using the Mamdani method, namely: (1) Fuzzification, (2) rule evaluation, (3) aggregation of the rule output, and (4) Defuzzification. The first step is to take a sharp input, $x_{-}$0dany_0, and determine the extent of where these inputs belong to each of the corresponding fuzzy sets. In the second step, if the given fuzzy rule has multiple antecedents, the fuzzy operator (AND or OR) is used to get a single number that represents the antecedent evaluation result. To evaluate the separation of the rule's antecedents, one uses the fuzzy OR operation. Next in step three, the membership functions of all consequent rules previously truncated or scaled are combined into a single fuzzy set. As for step four, the most popular defuzzification method is the centroid technique. More easily, [10] said that to get the output from the Mamdani method, four stages are needed, formation of fuzzy sets; application of implication functions; composition of rules and 4) defuzzification.

Furthermore, a simple example will be given related to the use of the Mamdani method to predict the amount of production of one of the basic needs, namely rice, if it is known that the community's rice needs and availability in Bulog. The data used for this example is data from BPS relating to the availability of rice commodities in Indonesia in the period 2006 to 2017 [4]. Based on data from BPS, information is obtained that the lowest amount of production in that year was $54,454,947$ tons (2006), while the highest production amount occurred in 2017 with a total of 79,175,945 tons [26]. The lowest rice availability occurred in 2006 with 54,506. 436 tons, while the highest rice availability occurred in 2017 with a total of 79,682,632 tons. On the other hand, based on BPS data, it is also known that the smallest national demand for rice occurred in 2007 with a total of $20,587,547$ tons, while the largest amount occurred in 2017 with the total demand for rice reaching $22,847,706$ tons.

In this case, there are three variables, namely: 2 input variables, including the need variable and the supply variable, while for output there is 1 variable, namely: rice production. The need variable has 2 linguistic values, namely up and down, the inventory variable has 2 linguistic values, namely a lot and a little, while the production variable has 2 linguistic values, namely increasing and decreasing. Rice production uses the following four fuzzy rules.

- $\quad$ [R1] IF demand DOWN and supply A LOT, THEN production is LESS

[R2] IF demand is DOWN and inventory is LITTLE, THEN production is LESS

- $\quad[\mathrm{R} 3]$ IF demand increases and supply is MANY, THEN PRODUCTION INCREASE

- $\quad[\mathrm{R} 4]$ IF demand increases and supply is LITTLE, THEN PRODUCTION INCREASE

The solution for this example using the Mamdani method of Fuzzy logic is as follows: 
J. Multidiscip. Appl. Nat. Sci.

1. Fuzzy Set Formation

The formation of fuzzy sets is the first step taken when using the Mamdani Method. There are three fuzzy variables to be modeled, namely:

Requirement: consists of two fuzzy sets, namely: DOWN and UP.

$$
\begin{aligned}
& \mu_{\text {KbtDoWN }}(x)=\left\{\begin{array}{l}
1 ; x<20.587 .547 \\
\frac{22.847 .706-x}{2.260 .159} ; 20.587 .547 \leq x \leq 22.847 .706 \\
0 ; x>22.847 .706
\end{array}\right. \\
& \mu_{\text {KbtUP }}(x)=\left\{\begin{array}{l}
0 ; x<20.587 .547 \\
\frac{x-20.587 .547}{2.260 .159} ; 20.587 .547 \leq x \leq 22.847 .706 \\
1 ; x>22.847 .706
\end{array}\right.
\end{aligned}
$$

Inventory: consists of two fuzzy sets, namely: LITTLE and MANY.

$$
\begin{aligned}
& \mu_{P s d D o W N}(x)=\left\{\begin{array}{l}
1 ; x<54.506 .436 \\
\frac{79.682 .638-x}{25.176 .202} ; 54.506 .436 \leq x \leq 79.682 .638 \\
0 ; x>79.682 .638
\end{array}\right. \\
& \mu_{P S d U P}(x)=\left\{\begin{array}{l}
0 ; x<54.506 .436 \\
\frac{x-54.506 .436}{25.176 .202} ; 54.506 .436 \leq x \leq 79.682 .638 \\
1 ; x>79.682 .638
\end{array}\right.
\end{aligned}
$$

Production: consists of two fuzzy sets, namely: REDUCE and ADD.

$$
\begin{aligned}
& \mu_{\text {ProdDown }}(x)=\left\{\begin{array}{l}
1 ; x<54.454 .937 \\
\frac{79.175 .945-x}{24.721 .008} ; 54.454 .937 \leq x \leq 79.175 .945 \\
0 ; x>79.175 .945
\end{array}\right. \\
& \mu_{\text {ProdUP }}(x)=\left\{\begin{array}{l}
0 ; x<54.454 .937 \\
\frac{x-54.454 .937}{25.176 .202} ; 54.454 .937 \leq x \leq 79.175 .945 \\
1 ; x>79.175 .945
\end{array}\right.
\end{aligned}
$$

\section{Application Function Implications}

For example, it is known that the total national rice demand in 2018 is $21,908,784$ tons and the total supply is $65,457,456$ tons of rice. The application used in this example is the MIN rule.

[R1] IF the need DOWN and supply a LOT, then production is LESS.

$$
\begin{aligned}
\alpha-\text { predicate }_{1} & =\mu_{\text {KbtDoWN }}(21.908 .784) \cap \mu_{\text {PsdLoT }}(65.457 .456) \\
& =\min \left(\mu_{\text {KbtDoWN }}(21.908 .784), \mu_{\text {PsdLoT }}(65.457 .456)\right) \\
& =\min (0,42 ; 0,58)=\mathbf{0 , 4 2}
\end{aligned}
$$

[R2] IF demand is DOWN and inventory is LITTLE, then production is LESS. Obtained

$\alpha$ - predicate $_{2}=0,42$.

[R3] IF supply increases and supplies ARE MANY, THEN INCREASED production $\alpha$ - predicat $_{3}=0,43$

[R4] IF needs UP and supply is LITTLE,
THEN PRODUCTION

INCREASE.

Obtained $\alpha$ - predicat $_{3}=0,57$

\section{Composition of Rules}

The method used to compose all rules is the MAX method. The membership function for the results of this composition is as follows.

$\mu(Z)=\left\{\begin{array}{l}0,43 ; \quad z<65207958,96 \\ \quad \frac{z-54.454 .937}{24.721 .008} ; \quad 65207958,96 \leq x \leq 68545911,56 \\ 1 ; \quad z>68545911,56\end{array} 6\right.$

\section{Defuzzifikasi}

The defuzzification method used is the Centroid method with a continuous domain, using the following formula.

$$
\frac{\int_{a}^{c} z \cdot \mu(z) d z}{\int_{a}^{c} \mu(z) d z}
$$

With this formula, the following results are obtained.

$z=\frac{924774972,1+443626018,4+112292638,7}{28363851,99+66876953,73+6006233,99}=14624592$

So for the example given gives results that the amount of national rice that must be produced if it is known that the need is $21,908,784$ tons of rice and the supply is $65,457,456$ tons is $14,624,592$ tons of rice.

\section{CONCLUSIONS}

Optimization of rice production by producers and optimization of the ordering of goods by distributors are important steps to maintain price stability for necessities in the market. Optimization of production and ordering of staple goods will have a significant impact on the financial sector because it is closely related to the prediction of the number of raw materials used, production costs, storage costs, and also distribution costs of goods. One of the fuzzy inference methods that can be used for this purpose is the Mamdani method. To get the output on the application of the fuzzy logic of the Mamdani method, four stages are needed, formation of fuzzy sets; application of implication functions (rules); composition of rules and defuzzification. Fuzzy logic Mamdani method can be used to predict the amount of national rice that must be produced. If it is known that the need is $21,908,784$ 
tons of rice and the supply is $65,457,456$ tons, the amount of national rice that must be produced is $14,624,592$ tons.

\section{AUTHOR INFORMATION}

\section{Corresponding Author}

Wawan Wawan - Department of Mathematics Education, Institute for Islamic Studies Ma'arif Nahdlatul Ulama (IAIMNU), Metro-34111 (Indonesia);

https://orcid.org/0000-0002-5573-623X

Email: awanwawan0215@gmail.com

\section{Authors}

Mai Zuniati - Department of English Education, Institute for Islamic Studies Ma'arif Nahdlatul Ulama (IAIMNU), Metro-34111 (Indonesia);

https://orcid.org/0000-0002-1231-1426

Agus Setiawan - Department of Mathematics Education, Institute for Islamic Studies Ma'arif Nahdlatul Ulama (IAIMNU), Metro-34111 (Indonesia);

https://orcid.org/0000-0002-9712-5461

\section{ACKNOWLEDGEMENT}

This work was supported by Lembaga Pengembangan Penelitian dan Pengabdian Kepada Masyarakat (LP3M) Institute for Islamic Studies Ma'arif NU (IAIMNU) Metro Lampung with Grant Number 108/LP3M/IAIM-NU/X/2019

\section{REFERENCES}

[1] V. Erokhin. (2017). "Factors influencing food markets in developing countries: An approach to assess sustainability of the food supply in Russia". Sustainability (Switzerland). 9 (8). 10.3390/su9081313.

[2] J. Premanandh. (2011). "Factors affecting food security and contribution of modern technologies in food sustainability". Journal of the Science of Food and Agriculture. 91 (15): 2707-2714. 10.1002/jsfa.4666.

[3] E. R. Adiratma. (2004). "Stop Tanam Padi?: Memikirkan Kondisi Petani Padi Indonesia dan Upaya Meningkatkan Kesejahteraann- ya". Penebar Swadaya, Jakarta.

[4] Badan Pusat Statistik. (2019). "Distribusi Perdagangan Komoditas Beras Indonesia Tahun 2019”. BPS, Jakarta.

[5] D. Kumar and H. Ramakrishna. (2012). "Assessment of Supply Chain Agility Using Fuzzy Logic for a Manufacturing Organization". The IUP Journal of Supply Chain Management. 4: 7-15.

[6] S. S. Jamsandekar and R. R. Mudholkar. (2013). "Performance Evaluation by Fuzzy Inference Technique". International Journal of Soft Computing and Engineering (IJSCE). 3: 2231-2307.

[7] Wang Li Xin. (2009). "A Course in Fuzzy Systems and Control". Pretince-Hall International, USA.

[8] L. A. Zadeh. (1973). "Outline of a New Approach to the Analysis of Complex Systems and Decision Processes". IEEE Transactions on Systems, Man and Cybernetics. 3 (1): 28 44. 10.1109/TSMC.1973.5408575.

[9] M. Mehrdad and A. NA. (2011). "Supplier performance Evaluation Based on Fuzzy Logic". International Journal of Applied Science and Technology. 1 (5): 257-265.

[10] S. Kusumadewi and H. Purnomo. (2010). "Aplikasi Logika Fuzzy untuk Pendukung Keputusan”. Graha Ilmu, Yogyakarta.

[11] A. M. Sánchez and M. P. Pérez. (2005). "Supply chain flexibility and firm performance: A conceptual model and empirical study in the automotive industry". International Journal of Operations and Production Management. $\quad 25 \quad$ (7): $681-700$. 10.1108/01443570510605090.

[12] U. O. Ezutah and Y. W. Kuan. (2009). "Supply Chain Performance Evaluation: Trends and Challenges". American Journal of Engineering and Applied Sciences. 2 (1): 202-211. 10.3844/ajeassp.2009.202.211.

[13] S. S. L. Chang and L. A. Zadeh. (1996). "On Fuzzy Mapping and Control”. IEEE transactions on systems, man, and cybernetics. 2: 180-184. 10.1142/9789814261302 0012.

[14] E. H. Mamdani and S. Assilian. (1975). "An experiment in linguistic synthesis with a fuzzy logic controller". International Journal of Man-Machine Studies. 7 (1): 1-13. 
J. Multidiscip. Appl. Nat. Sci.

10.1016/S0020-7373(75)80002-2.

[15] E. H. Mamdani. (1976). "Advances in the linguistic synthesis of fuzzy controllers". International Journal of Man-Machine Studies. 8 (6): 669-678. 10.1016/S0020-7373(76) $\underline{80028-4}$.

[16] M. A. Baten and A. A. Kamil. (2010). "Optimal fuzzy control with application to discounted cost production inventory planning problem". WCE 2010 - World Congress on Engineering 2010. 3: 1898-1902.

[17] K. A. Halim, B. C. Giri, and K. S. Chaudhuri. (2008). "Fuzzy economic order quantity model for perishable items with stochastic demand, partial backlogging and fuzzy deterioration rate". International Journal of Operational Research. 3 (1): 77-96. 10.1504/ IJOR.2008.016155.

[18] A. Nagoor Gani and S. Maheswari. (2010). "Supply chain model for the retailer's ordering policy under two levels of delay payments in fuzzy environment". Applied Mathematical Sciences. 4 (21): 1155-1164.

[19] H. M. Lee and J. S. Yao. (1998). "Economic production quantity for fuzzy demand quantity and fuzzy production quantity". European Journal of Operational Research. 109 (1): 203-211. 10.1016/S0377-2217(97)00200-2.

[20] C. Y. Lo, J. H. Leu, and C. I. Hou. (2007). "A study of the EPQ model using Fuzzy AHP when flaw of the products or unreliable machineries exists". IEEM 2007: 2007 IEEE International Conference on Industrial Engineering and Engineering Management. 7 (1): 163-1170. 10.1109/IEEM.2007.4419375.

[21] S. H. Chen and S. M. Chang. (2008). "Optimization of fuzzy production inventory model with unrepairable defective products". International Journal of Production Econom-

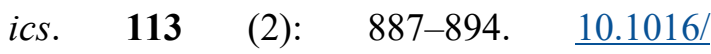
j.ijpe.2007.11.004.

[22] S. C. Chang. (1999). "Fuzzy production inventory for fuzzy product quantity with triangular fuzzy number". Fuzzy Sets and Systems. 107 (1): 37-57. 10.1016/S0165-0114 (97)00350-3.

[23] D. C. Lin and J. S. Yao. (2000). "Fuzzy economic production for production inventory". Fuzzy Sets and Systems. 111 (3): 465-495.
10.1016/S0165-0114(98)00037-2.

[24] S. H. Chen, C. C. Wang, and S. M. Chang. (2007). "Fuzzy economic production quantity model for items with imperfect quality". International Journal of Innovative Computing, Information and Control. 3 (1): 85-95.

[25] I. Iancu. (2012). "A Mamdani Type Fuzzy Logic Controller, Fuzzy Logic - Controls, Concepts, Theories and Applications". InTech, London.

[26] O. R. Prasetyo, R. R. Amalia, R. Gunawan, M. Hartini, N. G. P. A. S. Lestari, R. Poerwaningsih, and K. Astuti. (2018). "Luas Panen dan Produksi Beras di Indonesia 2018 (Hasil Kegiatan Pendataan Statistik Pertanian Tanaman Pangan Terintegrasi dengan Metode Kerangka Sampel Area)". Badan Pusat Statistik, Jakarta. 